\title{
Evidence of a Winning-cohesion Tradeoff under Multi-winner Ranked-choice Voting
}

\author{
Jack Santucci* \\ November 17, 2017 \\ Forthcoming in Electoral Studies
}

\begin{abstract}
New interest in "multi-winner ranked-choice voting" raises old questions about effects on party cohesion. Earlier writers thought this single transferable vote (STV) rule was net-problematic for parties. This paper consults the roll-call record in Cincinnati (1929-57) and Worcester, Mass. (1949-60), two of three American STV implementations that produced conventional wisdom. First, I show how party cohesion could be high or low. Then I show how low-cohesion terms followed elections in which candidates campaigned for themselves over their parties. Finally, I show that parties endorsed such candidates when they needed the votes to expand their seat shares. In sum, the data suggest a strategic environment in which majorityseeking parties reach beyond their traditional bases - potentially at the expense of legislative cohesion. Whether that is good or bad depends on the value we give party discipline.
\end{abstract}

Keywords: ranked-choice voting, single transferable vote, party cohesion, party change.

*The author thanks Georgetown University's Massive Data Institute for funding required travel. Hunter Books and Jasmine Underwood helped get and/or enter the data. Carolyn Ford, Paulette Leeper, and Amy Searcy of the Hamilton County Board of Elections provided election returns for Cincinnati. Niko Vangjeli of the Worcester Election Commission found his city's election returns, which Howard Fain in turn had rescued from the attic of Robert Bowditch, Sr. On the paper, Kent Weaver, Matthew Shugart, Hans Noel, and Dan Hopkins gave invaluable feedback. Contact: jack@voteguy.com. 
U.S. Representative Don Beyer (D-VA) has introduced legislation to use multi-winner ranked-choice voting for U.S. House elections. Meanwhile, organizers in Amherst (MA) and Santa Cruz (CA) hope to join Cambridge (MA) and Minneapolis in using it for local elections. In political science and around the world, this system is known as proportional representation via the single transferable vote - hereafter STV. ${ }^{1}$

The Beyer proposal leaves party leaders few ways to deny people access to office. By lowering electoral thresholds in primaries as well as general elections, the STV bill would give small groups an easier path to power than the current system, wherein party leaders retain significant influence over who can win a primary election (Salam and Richie 2017; Hassell 2015; Cohen et al. 2008). Reformers' proposal for local elections is even more extreme: nomination by petition. Twenty-three cities adopted and repealed this type of STV between 1915-62 (Weaver 1986; Amy 1993, 1996, 2002).

Seeing potential for a more fluid two-party system, scholars like Drutman (2016) and Lijphart (2015) argue STV would lessen polarization. By opening government to major-party outsiders, STV would reduce legislative cohesion, allow coalitions to shift, and generate policy more reflective of society's underlying diversity. An earlier generation of advocates made virtually identical arguments (Hoag and Hallett 1926; Hallett 1937).

The last time Americans used STV, however, advocates contended with sustained scholarly resistance. Much of it came from Hermens (1940, 1941, 1943, 1984), who lectured widely on "the breaking-up of parties." Following STV's repeal in every city but Cambridge, Banfield and Wilson (1966:97) proclaimed that "PR breaks down party control over nominations and permits mavericks who owe nothing to party leaders to win office." This paper returns to two of their three cases - Cincinnati and Worcester (MA) - to see if quantitative data support their anecdotal claim. ${ }^{2}$

I argue that parties in STV elections face a tradeoff between winning and cohesion. Because popular candidates can run and win on their own, parties have to choose whether to try to co-opt them. Putting resources behind those candidates can yield more seats in an assembly. The price, however, can be lower caucus discipline.

1. Cambridge has used STV to elect its city council and school committee since 1941. Minneapolis voters in 2006 approved STV for Park and Recreation Board elections.

2. Banfield and Wilson drew exclusively on two qualitative-descriptive accounts by Banfield's own Joint Center for Urban Studies (Harvard/Massachusetts Institute of Technology): one on Cincinnati (Gray 1959) and one on Worcester (Binstock 1960). 
My data are indices of party cohesion measured at the ends of legislative terms, then logically derived measures of electoral coordination preceding each of those terms. I focus on electoral coordination because, if a party's candidates campaign as a team, we might expect them to govern as one. All the data come from previously paper-bound roll-call and electoral records. They cover 20 elections, 20 council terms, 688 candidacies, and 180 victors (including party and party-factional affiliations in non-partisan elections).

This research design does not let me say whether party discipline is guaranteed to be lower with STV - for instance, by comparing otherwise similar cities with and without that rule. Collection of the data one would need has only just begun (Austin 2002; Bucchianeri 2017; Burnett 2017). What I can show are endorsement dilemmas and levels of party coordination that precede lower or higher cohesion in government. The findings are consistent with literature on how nominations condition electoral rules' effect on party cohesion.

Finally, I contribute to a new debate about the merits of ranked-choice voting $(\mathrm{RCV})$. One branch of this work covers voter error, voter turnout, and ballot roll-off in single-winner RCV elections (Neely et al. 2005; Neely and Cook 2008; Schultz and Rendahl 2010; Burnett and Kogan 2015; Neely and McDaniel 2015; McDaniel 2016; Kimball and Anthony 2016). A second emerging area focuses on voters' (Tolbert 2014; Donovan et al. 2016) and candidates' (Donovan 2014) perceptions of campaign tone in both singleand multi-winner (i.e., Cambridge) races. ${ }^{3}$ This is the first paper to consider American legislative politics under RCV of either type. While STV does not cause low party discipline, it does not guard against it. Understanding why that is allows us to modify the rule if we deem party discipline important.

First I explain how STV works. Then I review literature on electoral systems and party discipline. Section three illustrates the variation in my sample. Section four states and tests hypotheses about the relationship between electoral coordination and party cohesion under STV. Section five turns to motive. I show that low-cohesion parties were those that needed more seats, tended to endorse people who might have won as independents, and tended to reflect less campaign "team spirit" as a result. The final section addresses limits in the application of these findings, then how one might change STV if one wanted higher cohesion.

3. See also Kimball and Anthony (2018). 


\section{Basic mechanics of STV}

Under STV, the voter ranks candidates in order of preference. The number of votes needed to win one seat depends on the size of a district. In a district of three seats, which is the minimum proposed in Beyer's bill, a candidate would need 25 percent of votes plus one to win. ${ }^{4}$ Votes in excess of that 25 percent are "surplus" and transfer to whomever that candidates' supporters have ranked next. Similarly, candidates not clearing that 25 percent are eliminated one at a time, and their votes pass on to whomever is ranked next on the ballots cast for them. The vote count iterates between surplus transfer and sequential elimination until all seats are filled.

\section{Electoral rules affect cohesion via nomination}

I argue that STV causes low party discipline when seat-maximizing parties nominate candidates apt to challenge their parties' positions. How is this argument consistent with existing scholarship on comparative party discipline?

Parties aim for control of government in order to deliver policy, and those two goals can conflict (Schwartz 1989; Aldrich 1995). In the presidencycentered narrative of Bawn et al. (2012), interest groups paper over their differences in order to elect a chosen candidate. Inaction on points of disagreement is a source of disunity, and it causes realignment in the long term (Miller and Schofield 2003; Karol 2009). Bergman and Shugart (2013) reason from the same basic position in their comparative work on legislative elections. Focusing on low-threshold, candidate-based electoral systems, they note that the interests of "vote-seeking candidates" can be more or less aligned with the needs of "collective seat-maximizing parties." Generally speaking, there is a tradeoff between winning elections and delivering every member's favorite policy.

Do electoral systems affect the tradeoff? One research tradition implies they do not. Some of this work has focused on Brazil, a presidential system in which legislators are elected under open-list proportional representation

4. A Droop quota $(Q)$ is a function of the sum of valid first-preference votes cast in an election $(V)$ and district magnitude $(M)$ :

$$
Q=\frac{V}{M+1}+1
$$


(PR). For example, Limongi and Figueiredo (1995: 500) saw that Rice cohesion scores varied, and they explained that variation in terms of chamber leaders' ability to prevent caucus-splitting bills from coming to a vote. Ames (2001: 187-223) looked at the same legislature and saw that party unity scores were higher when parties could agree internally on geographically targeted spending packages. In a similar vein, Tavits (2009) compares five European parliamentary democracies because these should have higher party discipline than presidential systems. The rules in her five cases range from not-at-all to highly candidate-centered. She finds that politicians with local political experience are more likely to defect from majorities of their parliamentary parties, regardless of institutions.

U.S. Congress scholars might note that discipline has varied while voting rules have not. Congressional elections always have been candidatebased and, since 1842, overwhelmingly in single-member districts (Calabrese 2006)..$^{5}$ Compared to present levels, however, party discipline in the 1960s80s was low. This is true across a range of metrics: average Rice cohesion scores, NOMINATE-based measures of polarization, agenda-corrected measures of the proportion of party-unity votes by Congress, partisan division on votes to empower chamber leaders, floor-speech rhetoric, fundraising coordination, and so on (Mayhew 1974; Cain et al. 1987; Poole and Rosenthal 1997; Crespin et al. 2011; Pearson 2015).

Once we introduce variation on electoral systems, however, mixed results emerge. Desposato (2006) finds that adjusted Rice cohesion scores were similar in the Brazilian Chamber of Deputies and Senate, 1991-2003, the electoral systems of which are different. Two studies of the Russian Duma found higher defection rates among deputies elected in single-member districts (SMD) than their co-partisans elected from closed PR lists (Haspel et al. 1998; Kunicova and Remington 2008). Jun and Hix (2010) find similar behavior in the $17^{\text {th }}$ Korean National Assembly, following a change to mixed SMD/list-PR elections. ${ }^{6}$ Olivella and Tavits (2013) find that defection rates increased in the Hungarian parliament, 1994-2010, following a move from closed-list PR to SMD elections. At the same time, cohesion did not increase with the move back. Finally, Carey (2007) finds lower party cohesion among Western democracies whose rules permit intra-party competition.

5. Rare deviations from single-member plurality include at-large plurality, or the "general ticket," and the numbered post system.

6. Consistent with the argument in this paper, Jun and Hix (2010:158-9) attribute parties' tolerance of defection to their desire to maximize seat shares. 
More recent work argues that effects of electoral systems depend on whatever nomination rules come with. For example, committees in 24 U.S. states' lower chambers, 1955-95, had more autonomy from partisan majorities when those states held open primaries (Bagashka and Clark 2014). Alvarez and Sinclair (2012) find that California legislators, 1975-2006, voted more often with members of the opposing caucus when those legislators were nominated in blanket primaries. Yael Shomer has a series of cross-national analyses showing how party discipline suffers especially in candidate-based systems with permissive nominating rules, e.g., when primary voters choose nominees instead of party leaders (Shomer 2017, 2016). Finally, one can find defection even under closed-list systems, especially among people who appear higher on party lists (Stegmaier et al. 2016). Why would that be? Legislators with lower list positions need the party to get elected - but the party may need list-topping "mavericks" to boost its overall vote share.

What about STV and party discipline? The effect likely also depends on the sorts of people nominated. Carey and Shugart (1995) noted early on that "open-endorsement" STV (i.e., with nomination by petition) would free aspiring legislators to run on non-party platforms. Qualitative accounts of STV in the United States were based on open-endorsement STV. Polemic aside, proponents and detractors agreed it would not (and eventually did not) promote party discipline (Hoag 1923; Hoag and Hallett 1926; Hermens 1941, 1943; Banfield and Wilson 1966).

Outside the United States, STV comes with many tools of nomination control. In Malta, for example, party organizations can refuse to nominate candidates, and candidates on ballots are grouped by party (Hirczy de Miño and Lane 1996). Australia gives voters the option to ratify party-given preference orderings in Senate elections. The vast majority take it, which effectively turns STV into closed-list PR. Ticket-splitting is therefore rare in both countries (Farrell and Katz 2014:15). Finally, in Ireland, no person may be a candidate without a Certificate of Party Affiliation, and no person may receive such a certificate without signatures from one or more party officers (Citizens' Information Board 2017a, 2017b).

Perhaps as a result of such party control, few remark on poor cohesion in STV countries. Owens' (2003) survey of advanced industrial democracies makes no mention of problems in the Australian Senate. Scholars hold up Malta's party system as one that defies conventional STV wisdom (Hirczy de Miño and Lane 1996, 2000). Sinnott (1999:117) reports high rates of discipline in Ireland, and Depauw and Martin (2009) note these are among 
the highest in Western Europe.

\section{Historic context and dependent variable}

I begin with a description of the data and the context that produced it. Twenty-four American cities adopted open-endorsement STV in the first half of the $20^{\text {th }}$ century. Twenty-three of these instances came with councilmanager city charters. This is because the Proportional Representation League, which had unsuccessfully promoted PR since 1893, appealed to the National Municipal League (NML) in 1913 with a new "representative council plan" for city government (Thompson 1913; Hoag 1914). This became the NML's model city charter from 1914-64: council-manager government, at-large elections to councils of seven or nine, nomination by petition, and STV elections (Frederickson et al. 2004). Ashtabula (OH) became a test case for that charter in 1915 (Hatton 1916; Busch 1995).

The cohesion problem noted by later STV critics soon appeared in Ashtabula. Proponents said its council was more representative than those of nearby cities with similar, non-STV charters (Moley 1918). Detractors noted it took more than fifty ballots to choose the city manager (Hermens 1941:366). An early Master's thesis described several simultaneous cleavages - over prohibition, ethnic identification, and the Ku Klux Klan - but did not say whether they overlapped or cross-cut each other (Bloomfield 1926).

To solve the apparent discipline issue, reformers began promoting the idea of pre-election coalition (Hoag and Hallett 1932). They recommended merging those groups that had backed STV in the first place, presenting a common slate, and asking voters to rank only members of that slate. The most prominent example of this device appeared in Cincinnati, where a coalition of regular Democrats and Progressive Republicans imposed STV in 1924 (Kolesar 1995). The NML appealed widely to the success of this "Cincinnati experiment" in an effort to export the model to 17 more cities nationwide (Taft 1971).

This paper focuses on Cincinnati and Worcester for several reasons. First among them is their place in the STV historiography. Banfield and Wilson (1966) generalized about the discipline problem on the basis of experience in only these two cities, plus New York City, which had an entirely different sort

of city charter. ${ }^{7}$ Second, institutions in these cities were both identical and

7. New York retained a strong mayor and bicameral structure. STV was used for lower- 
representative of the wider STV universe: city-wide elections to nine-seat, unicameral councils. Third, these cities were among those with the longest uses of STV, which means they provide much over-time variation to explain. Fourth, they tap the U.S. experience with STV, which clustered in three states: five cities in Ohio, seven in Massachusetts, and three in New York. ${ }^{8}$

The party systems were as follows. In Cincinnati, Progressive Republicans were in tense coalition with the regular Democratic Party, jointly opposing the regular Republican party (Reed et al. 1957). That coalition was called the Charter Party. Worcester offered a reverse image of Cincinnati's arrangement. The Citizens' Plan E Association (CEA) pitted reformist Democrats and the Republican Party against the regular Democratic Party (Binstock 1960). ${ }^{9}$

Figures 1 and 2 let us visualize these party systems. I have applied a twodimensional, non-parametric, spatial model to the roll-call voting records of each city. This optimal classification (OC) method generates coordinates that maximize correct prediction of voting decisions, as its name implies (Poole 2000, 2005). For each city, I combine all sessions into a single voting matrix. ${ }^{10}$ Because we are interested in party cohesion, I have estimated these ideal points with what Rosenthal and Voeten (2004) call a "party-switcher model." This means treating legislators who switch parties as different people. ${ }^{11}$

chamber elections. The size of the council fluctuated with voter turnout, and seats were apportioned at the borough level (Tanzer 1937).

8. Analysis of the New York City records is in progress.

9. Plan E associations were common across the Massachusetts cities except Cambridge, where the coalition was known as the Cambridge Civic Association, or CCA. Plan E was the state-law designation for a council-manager STV charter.

10. In each case, I have set the polarity of the first dimension with a long-serving member of the largest regular party (Democrat James D. O'Brien in Worcester, Republican James G. Stewart in Cincinnati) and that of the second dimension with a long-serving member of the faction that defected from it (reformist Democrat Thomas C. Sweeney in Worcester, Progressive Republican Russell Wilson in Cincinnati).

11. The data comprise 20 elections, 20 council terms, 688 candidacies, and 180 victors. Cincinnati roll-call votes are from The City Bulletin: Official Publication of the City of Cincinnati. Worcester roll calls are photographed and entered from original minutes, on file at Worcester City Hall. Party affiliation data for Cincinnati come from Results of Elections in Hamilton County, supplemented by biennial, pre-election issues of the Cincinnati Enquirer. Party data for Worcester are from biennial, pre-election issues of the Worcester Telegram, CEA endorsement records from the Worcester Historical Museum, and voter registration index cards on file at the Worcester Election Commission. All photographs are on file with the author. 


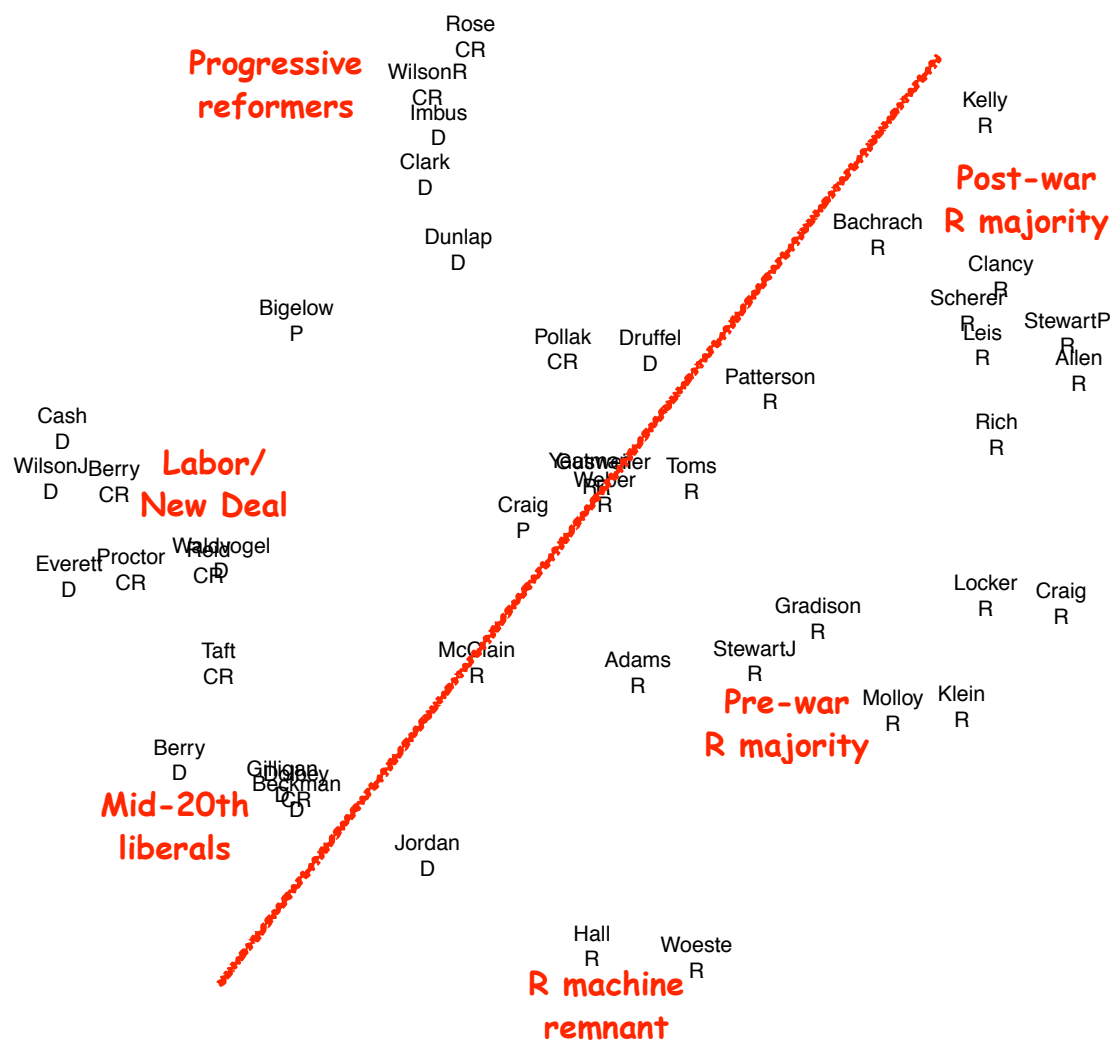

$95.9 \%$ of votes correctly classified.

APRE $=0.851$.

Figure 1: Spatial representation of voting in the Council of the City of Cincinnati, 1930-57. $\mathrm{CR}=$ Charter Republican, $\mathrm{D}=$ Democrat (part of Charter), $\mathrm{P}=$ Progressive Democrat, $\mathrm{R}=$ regular Republican. 


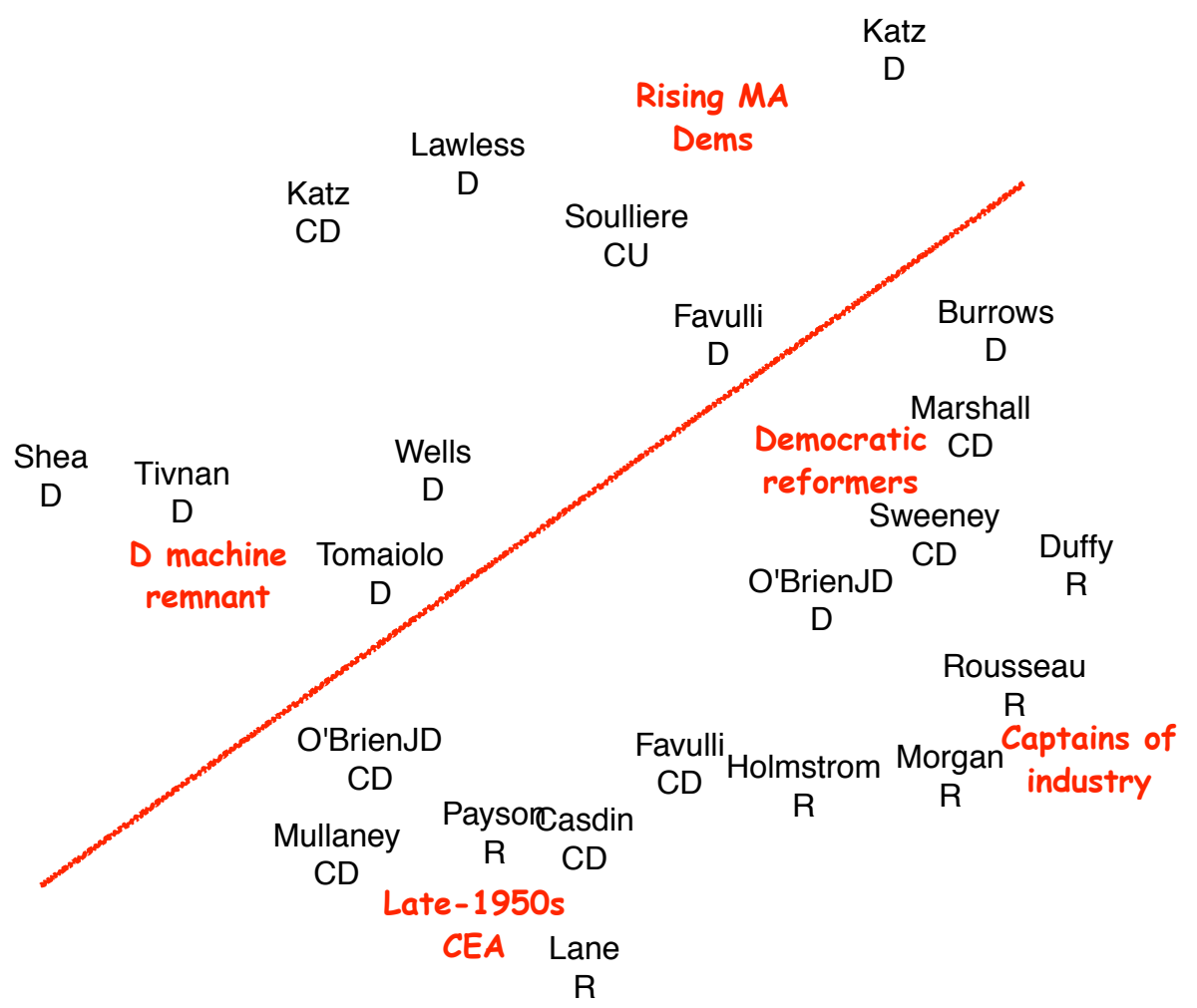

$94.7 \%$ of votes correctly classified.

APRE $=0.799$.

Figure 2: Spatial representation of voting in the Worcester City Council, 1950-60. $C D=C E A$ Democrat, $C U=C E A$ unaffiliated, $D=$ regular Democrat, $\mathrm{R}=$ Republican (part of CEA). 
Two key points stand out in each plot. The first is an overall division between the coalition elements (Charter, CEA) and the regular, opposing parties. The diagonal lines running from top-right to bottom-left help us see this. For Cincinnati, only one person appears on the wrong side of this line: Charter Democrat Albert C. Jordan, a local union boss who began voting with Republicans after Progressive Republicans broke ranks with the rest of Charter on pro-labor legislation in the mid-1950s. ${ }^{12}$

We see the same overall division in Worcester, where just four people appear on the wrong side of the line. One is Israel "Izzy" Katz, a CEA Democrat who eventually joined the regular Democratic party and, later in the 1970s, became Mayor of Worcester. The second is Paul Soulliere, an unaffiliated CEA endorsee about whom we know very little. Regular Democrats on the CEA side of the line are Alan K. Burrows, also a mystery, and James D. O'Brien. O'Brien made a successful transition from member of the pre-reform "machine" to CEA-endorsed mayor in the late 1950s. His alignment with CEA Democrats toward the right of the space may reflect his courting of that group. In November 1957, O'Brien replaced Thomas C. Sweeney as leader of the Democrats aligned with CEA. ${ }^{13}$

The second point to note is varied party discipline. We see distinct voting blocs on either side of the line in each plot, but the blocs on any given side do not form one coherent mass. I think this patterning represents a series of ongoing, local-level realignments. ${ }^{14}$ Consider any voting bloc and the group directly opposite.

In Cincinnati, Progressive Reformers of the late 1920s-early 1930s (top) oppose whatever remained of the pre-reform Republican Party (bottom). Some of those Republicans go on to serve in the Republican majority of the late-1930s and early 1940s (lower right), which itself is opposite a group of New Deal Democrats and labor-aligned reform Republicans (left). Later on, we see a group of primarily racial liberals opposing the 1950s Republican party (Heisel 1982), which includes conservatives like I-know-it-when-I-see-it Potter Stewart, eventual Associate Justice on the U.S. Supreme Court, and a group of eventual U.S. Representatives: anti-Communist crusader Gordon Scherer, Goldwater acolyte William Cody Kelly, and Donald D. Clancy

12. The author, unpublished.

13. The author, unpublished.

14. Hans Noel (2016) finds a similar spatial structure in ideal points from the U.S. House of Representatives, 1940-80, with two orthogonal cleavages: Republican versus Democrat, then liberal versus conservative. 
(Straetz 1958).

Worcester's policy space reflects similar variation. Early CEA Democrats (right) are opposite the Democratic "machine" remnant (left), which also opposes the regular Republicans (lower right). Regular Republicans stand between the first- and second-generation CEA blocs, the latter of which (bottom) opposes three regular Democrats who went on to successful careers in state politics (top): Mike Favulli, Izzy Katz, and John Lawless (Binstock 1960).

One might be tempted to say the main line of cleavage rotates through a two-dimensional ideological space. Alas, the titles of the bills make it difficult to say what the $\mathrm{x}$ - and $\mathrm{y}$-axes substantively represent. I reserve that job for later work.

How do the ideal point estimates compare to those from cities without STV? Peter Bucchianeri (2017) has the only other multi-city set of local-level roll-call data to date. ${ }^{15}$ While he does not yet have the party affiliation data needed to calculate cohesion indices, he reports the fit of one-dimensional OC models applied to multi-term voting matrices (as I have done here) from 132 modern city councils. Fit is the aggregate proportional reduction in error (APRE), which controls for the margins of roll-call votes when reporting how well a model classifies voting choices. Bucchianeri says the mean APRE for a one-dimensional model is 0.74 , with a range of 0.47 to 1 , and a standard deviation of 0.12. APRE for a one-dimensional OC model is 0.73 in Cincinnati and 0.55 in Worcester. Treating APRE as a rough proxy for voting cohesion, Cincinnati under STV is on par with the modern average, and Worcester registers toward the bottom of the range.

Figure 3 gives a different picture of party cohesion in each city - and the measure I will use in my analyses below. These are Rice (1925) cohesion scores, a standard way to measure party loyalty. Scores are averaged across all roll-call votes in a given term for a given party. Unanimous roll calls are omitted. We see that cohesion varies between about 0.4 and one ${ }^{16}$

15. Burnett (2017) has data from San Diego, 2008-9. Austin (2002) once had data from Alexandria (VA), Huntsville (AL), Raleigh (NC), Rochester, New York, and New Haven, 1987-96.

16. The Rice score $(R)$ for a single roll call in which party $p$ casts $Y$ yea votes and $N$ nay votes is:

$$
R_{p}=\frac{\left|Y_{p}-N_{p}\right|}{Y_{p}+N_{p}}
$$




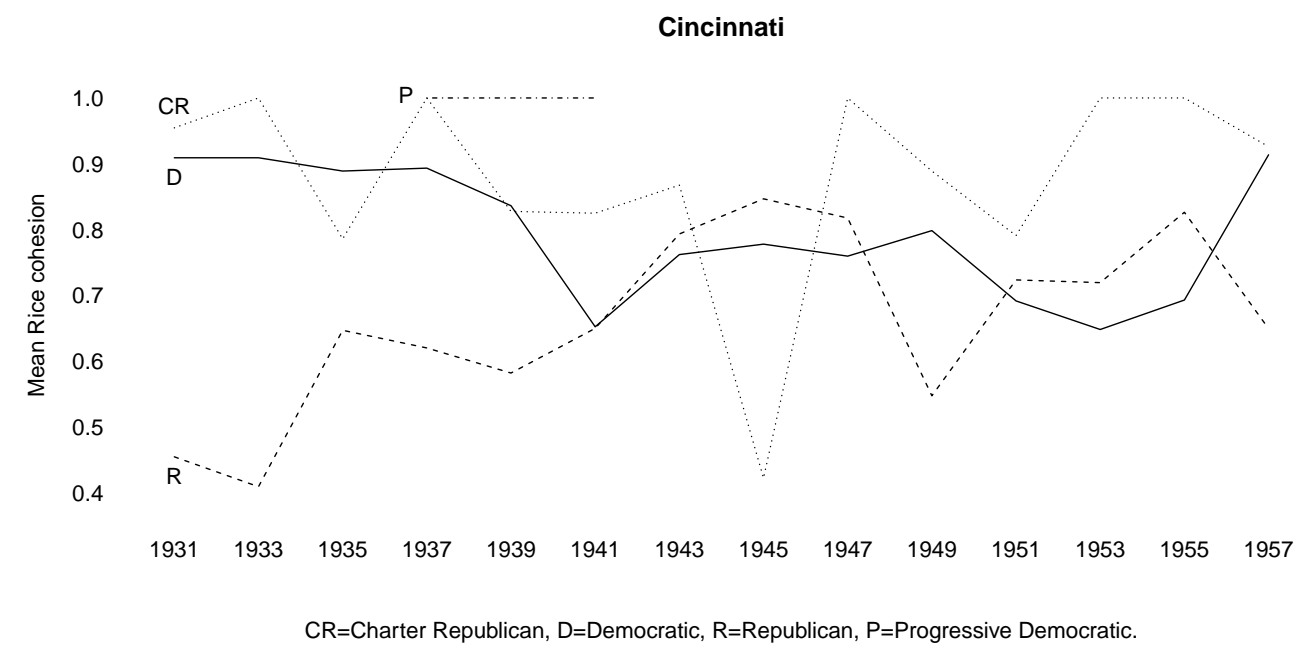

Worcester

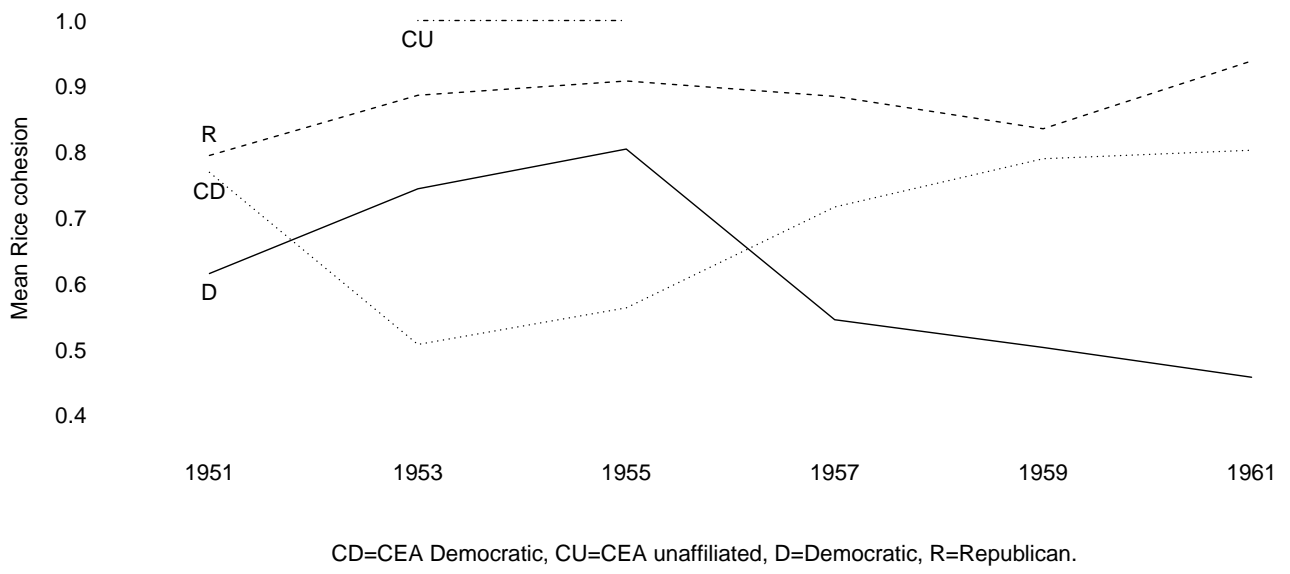

Figure 3: Party cohesion under STV in both cities. 


\section{Campaign as a team, govern as a team}

The literature tells us that electoral systems affect legislative cohesion via nominations. It also tells us that list systems sometimes produce low-cohesion groupings, even those with high nomination barriers like closed-list PR. The reason is that parties want to win control of government as well as stand for policy. That leads them to nominate popular candidates whose votes help elect the rest of a slate, even if those candidates divide their parties some of the time. I hypothesize that open-endorsement STV worked the same way. When a party needed more votes, it endorsed people who were apt to divide the caucus.

My first step is to show how varying "team spirit" in STV elections preceded different levels of party cohesion. This requires a sense of what constitutes a normal vote distribution among candidates, then what a distribution might look like when a seat-seeking party gropes for extra votes. First I consider those distributions under a normal STV election. Then I consider them in light of a quirk in council-manager cities: the election doubled as a test of who might be elected chamber leader.

\section{Strategic coordination in normal STV}

A seat-maximizing, STV party has two overarching worries. One is not to nominate too many candidates, but it is hard for a party to know what constitutes "too many." The second is to make sure that first-preference votes are spread evenly among the candidates it does nominate. That it can control. Assume that a party has nominated the optimal number of candidates, i.e., it has a good sense of its strength in the electorate. By definition, only one candidate can win in the first round of counting. The trick is to make sure each of those candidates survives elimination for as long as possible in an STV vote count. That way, they can garner additional votes as the count proceeds, either from other parties or from co-partisans who end up eliminated.

How does a party make sure its slate members survive elimination for as long as possible? A party cannot control what other parties have done, but it can manage its own vote. One way is to prevent same-party candidates from "spoiling" each other, i.e., causing early-round elimination by concentrating too many votes on too few candidates. The easiest way to do this is to make sure each candidate gets roughly the same share of first-preference votes (Cox 
1997: 144). In the comparative literature, this "vote management" strategy is known as "spread the preferences" (Clark 2012).

It would be easy to check whether a party's candidates have gone along with a preference-spreading strategy. One potential measure would be the gap between the actual and effective numbers of seat-winning candidates, computing the effective number from their proportions of their combined first-round vote. An absolute gap far from zero would indicate failure of electoral coordination, i.e., a failure to spread the preferences.

\section{Strategic coordination under the STV city charter}

STV as used in Cincinnati, Worcester, and elsewhere complicates the measurement of coordination. This is because candidates might be running for mayor at the same time they were running for office. It was convention to award the mayoralty to the highest-placed candidate from the majority. In the case of a coalition such as Charter or CEA, the mayoralty would go to the highest-placed candidate from whichever coalition party won more seats (Straetz 1958). It follows that a vote distribution preceding a term with higher than average party discipline ought to have one clear leader and fairly even vote shares for all other candidates.

Visually speaking, it is easy to see successful "city STV" coordination in printed election returns. Table 1 gives an example from Cincinnati, November 1953. Carl Rich was the Republican Party's candidate for mayor. His first-preference vote total is more than double that of any other Republican candidate. At the same time, the other Republicans have fairly even vote shares, indicating they spread their preferences.

Table 1 also contains an example of coordination failure. Focus on the Democrats. There are two potential party leaders. One is Ted Berry, President of the local National Association for the Advancement of Colored People (NAACP). The second is long-time Mayor Ed Waldvogel, a New Deal Democrat who selectively worked with Republicans on urban redevelopment in the 1940s. Redevelopment later put Berry and Waldvogel in conflict (Gray 1959: V-5). When the two entered council that December, in fact, the Charter coalition broke tradition by electing Waldvogel mayor. Berry had 1,153 more first-preference votes than Waldvogel. 


\begin{tabular}{llll}
\hline Candidate & Party & Round 1 & \% of quota \\
\hline Rich & R & 25,062 & 158 \\
Kelly & R & 11,643 & 73 \\
Clancy & R & 10,037 & 63 \\
Bachrach & R & 7,683 & 48 \\
Dolbey & CR & 6,843 & 43 \\
Berry & D & 14,831 & 93 \\
Waldvogel & D & 13,678 & 86 \\
Jordan & D & 10,290 & 65 \\
Gilligan & D & 8,085 & 51 \\
\hline
\end{tabular}

Table 1: Winners of the 1953 Cincinnati election ( $\mathrm{R}=$ Republican, $\mathrm{D}=$ Democrat, $\mathrm{CR}=$ Charter Republican).

\section{Two measures of coordination in elections}

We can capture the difference between good and bad coordination - e.g., between the Republicans and Democrats in Cincinnati's 1953 election - with two straightforward measures. The first is a concentration index of a party's winning candidates' vote shares. ${ }^{17}$ Assume a party with an arbitrary number of "minions," a party leader running for mayor, and a potential challenger. Assume the minions spread their preferences so that their vote shares are the same. Vote-share concentration will be higher when there is only one ticket leader. It will fall as a potential challenger approaches the vote share of the ticket leader.

There are two potential problems with the concentration index. The first is that, after some inflection point, it again begins increasing as the challenger's vote share approaches that of the party leader. This inflection point varies with raw votes for a minion as well as the raw votes for a leader. The second problem is that concentration varies systematically with the number of candidates included in the calculation. I propose two ways to deal with these issues.

To address systematic variation with the number of candidates, I compute a correction to vote concentration for a party of each size in the data. This value is the coefficient from a linear regression of the concentration index on party size alone. The idea here is to partial out whatever contribution party

17. Concentration is equal to the sum of squared vote proportions (Hirschman 1964). 
size makes, then subtract it from the observed value of vote concentration. Table 2 reports these values, using a party of two as reference category. As expected, each coefficient is very precisely estimated, and as party size increases, so does the size of the correction required.

\begin{tabular}{lrrrr}
\hline & Estimate & Std. Error & $\mathrm{t}$ value & $\operatorname{Pr}(>|\mathrm{t}|)$ \\
\hline Intercept & 0.55 & 0.02 & 30.93 & 0.00 \\
3 winners & -0.14 & 0.03 & -5.48 & 0.00 \\
4 winners & -0.27 & 0.03 & -9.96 & 0.00 \\
5 winners & -0.32 & 0.04 & -7.47 & 0.00 \\
\hline
\end{tabular}

Table 2: Using linear regression to partial out the effect of party size on the concentration index of winners' vote shares.

There is no clear way to correct the index for systematic effects of leader and minion vote-share sizes. Instead, I propose a second measure: the gap between leader and challenger vote shares. Technically speaking, this is the difference between the vote shares of the highest-placed candidate and runner up, with vote share calculated as proportion of the ticket leaders' combined share. If the challenger is really being a minion by going along with preference-spreading, the gap will be large.

Neither measure is perfect, but together they get at the relationship between coordination in elections and cohesion in a legislature. The concentration index captures slate-wide coordination but breaks down under some configurations of leaders and minions. The gap between the slate's leading candidates is robust to that problem but does not capture preferencespreading in the rest of the slate.

\section{Statistical tests}

I hypothesize that party coordination in elections ought to help predict the subsequent levels of legislative cohesion. Operationally, average Rice cohesion in a given legislative term should be higher when the preceding election reflects:

1. higher values of the size-adjusted concentration index of a party's winners' vote shares,

2. higher values of the gap between a party's top two winners. 
To test these two hypotheses, I estimate a battery of linear regression models, sequentially adding controls. My observations are party-terms. Following Carey (2007) and others, I omit the occasional party of one member. The first and most important control is party size. This is because Rice cohesion scores systematically inflate cohesion in small parties (Desposato 2005).

I also control for whether the party filled a vacancy over the course of a term. This may be a non-electoral shock to party discipline. Convention allowed a party to choose a member's replacement in the event of death or resignation. Narrative evidence suggests the Republican Party in Cincinnati used this power to increase caucus discipline (Straetz 1958). Finally, I add a dummy variable for Worcester, then replace it with fixed effects for cityterm.

Table 3 presents the results of all ten models. In each of the first five, higher values of adjusted vote-share concentration predict higher values of average Rice cohesion. In each of the last five, smaller gaps between the top two candidates (i.e., the "leader" and the "challenger") predict lower values of average Rice cohesion.

As expected, the vote-share concentration models better fit the data. That is because concentration captures the entire slate's behavior, while the top-two gap only focuses on the top two candidates. R-squared is better for each of these models than the corresponding gap model. ${ }^{18}$ The coefficients are more precisely estimated. The intercepts are smaller, have less explanatory power, and tend to hover around the average Rice values implied in Figure 3. Finally, adding the concentration coefficient to the intercept always produces average Rice cohesion within the range of possible values.

Figure 4 illustrates the relationship between party cohesion and coordination in the preceding election. Filled points are from Worcester, and hollow points are Cincinnati parties. Dashed lines represent the predicted values and 95-percent confidence interval of the concentration model with controls for party size and whether a vacancy was filled (both held at their sample means). As coordination improves, so does legislative discipline.

18. Adjusted R-squared does plummet when we add fixed effects for city-term. This is because fixed effects amount to 19 extra variables in a model with 56 observations. 


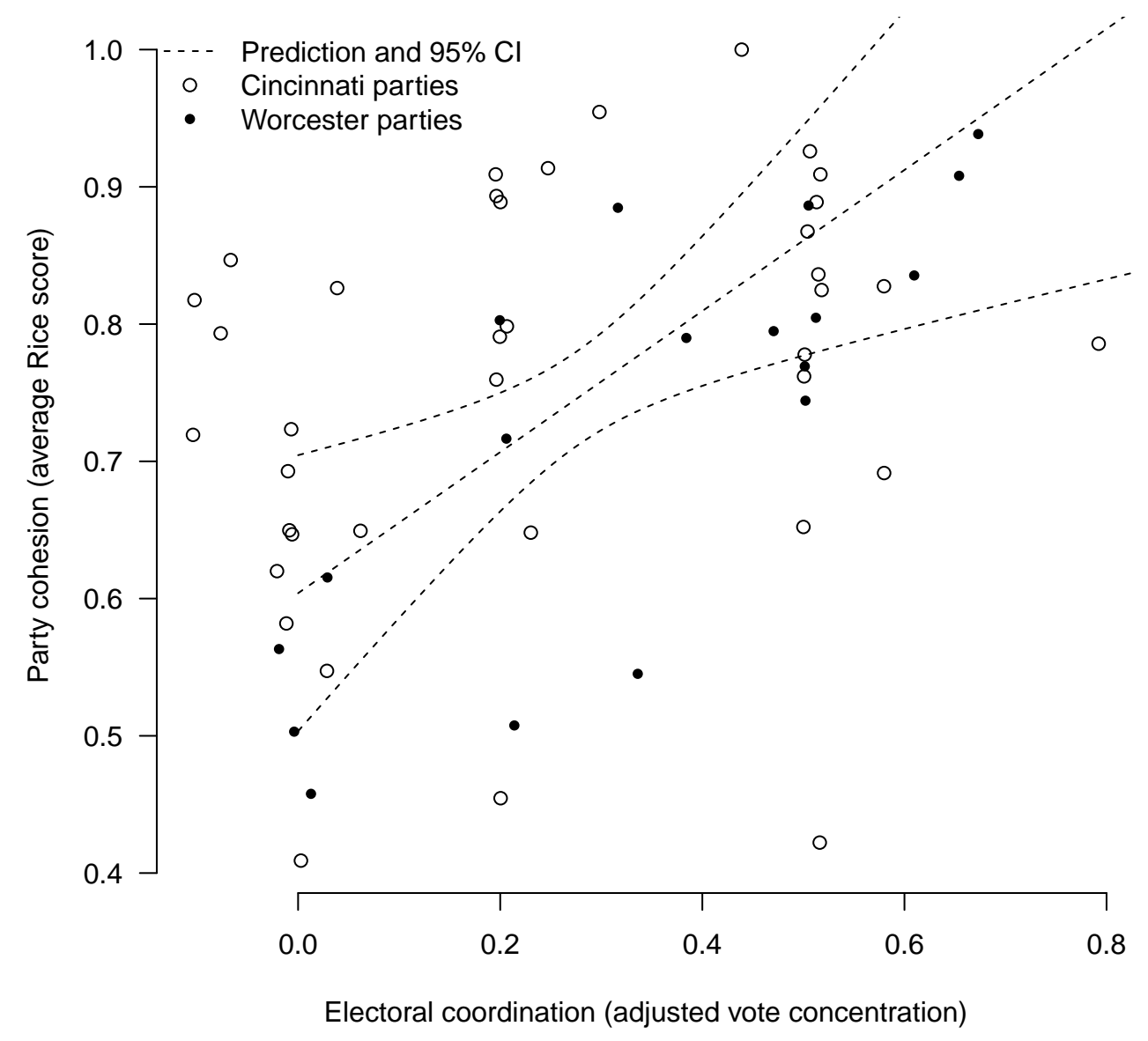

Figure 4: Relationship between legislative cohesion and successful coordination in the preceding election. 


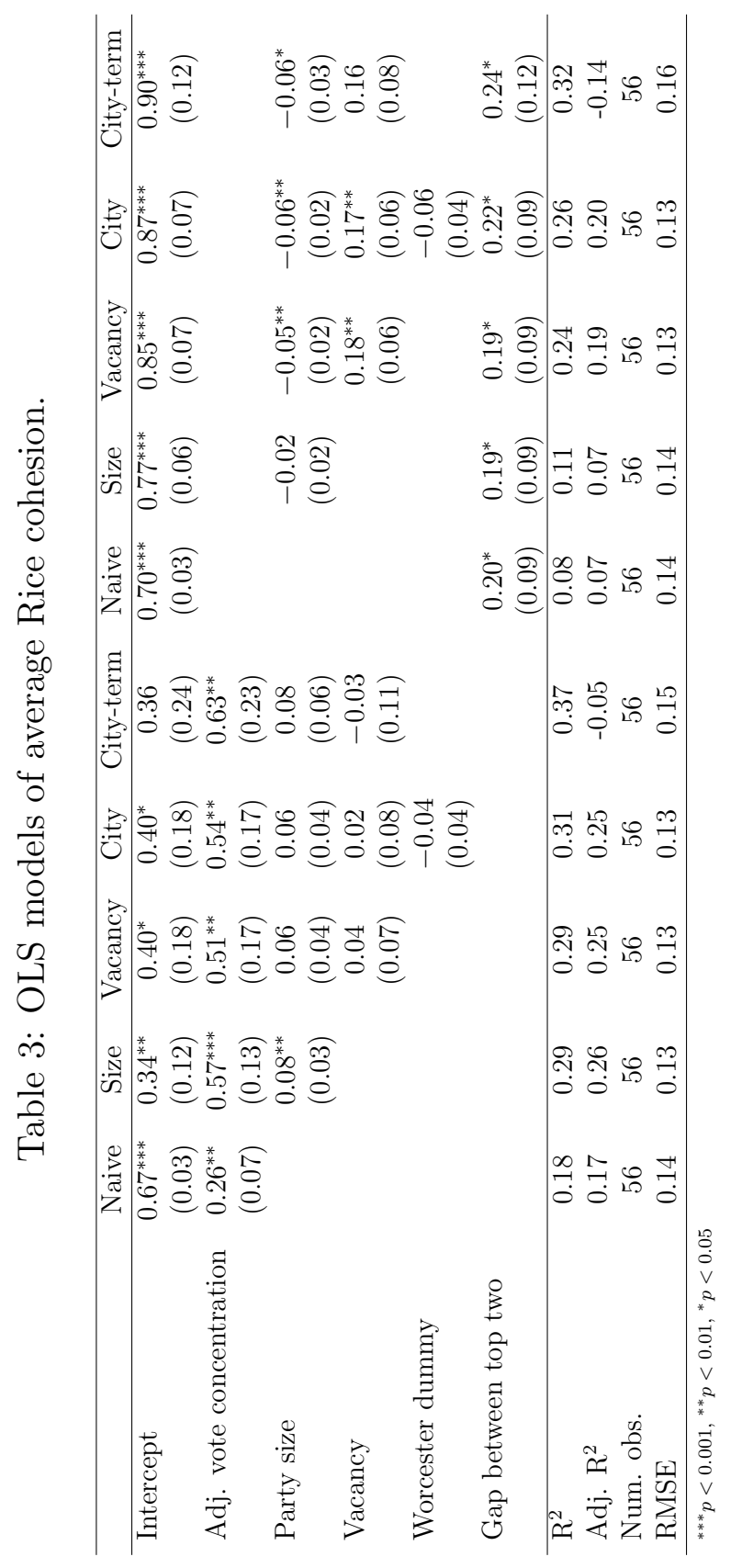




\section{Groping for votes to win more seats}

The last section showed that terms with lower than average cohesion tended to follow elections in which parties did not campaign as teams. I argued that a party campaigns as a team when it spreads its preferences to maximize the election of its candidates, so that the winners' vote shares are roughly even (accounting for the mayoral quirk in my cases). Candidates who care more about themselves than their parties are maximizing first-choice votes. Call this sort of candidate a "lone wolf."

Parties nominate lone wolves when they need the surplus votes in order to win more seats. As long as the lone wolf instructs their voters to rank within the rest of the slate, any transfer of surplus from the lone wolf will help elect co-partisans.

To show that seat-needing parties nominate lone wolves, I ask three questions about the parties in the bottom third of my Rice cohesion distribution. ${ }^{19}$ Was the party in the minority at the time of the election that produced the respective council? If so, it ought to have been groping for seats. If it was in a coalition, was it in the minority of that coalition? A party in a coalition's minority will grope. That is because it wants to be the majority of the majority, in order to win the mayoralty. Third, was there a detectable turn toward popular out-of-party candidates at the election preceding a lowcohesion term?

On average, parties needing more seats to dominate the council and/or a pre-election coalition were those that had the lowest cohesion levels. Table 4 presents the set. Of 18 parties, 12 of these were in the minority at the preceding election. ${ }^{20}$ Three more had been in the minority of a pre-election coalition. ${ }^{21}$

19. Size-induced bias in cohesion scores is not producing this subset. We see parties of every size existing in the sample. See Table 4.

20. I omit the 1950-1 term in Worcester because parties there did not yet have an STV electoral history to consult.

21. Special circumstances explain the remaining three terms. Low-cohesion Cincinnati Republicans in 1938-9 and 1940-1 had endorsed a labor lawyer, Nick Klein, in both of the preceding elections (Straetz 1958). This is because, in both elections preceding those, no one party or coalition had control of council. The Progressive Democratic ticket was fielding its own candidates and, for whatever reason, not making pre-election deals with either Charter or the Republicans (Kolesar 1995). Low cohesion among the Cincinnati Democrats of 1950-1 appears unrelated to endorsements. Note, however, that NAACP leader Ted Berry (referenced above) switched in this term from the Charter Republicans 
Might the candidates endorsed have won in their own right? That is, can we really call them "lone wolves"? One place to find a lone wolf is in the set who lost the last election. Figure 5 gives a quick look at the data. Bars represent the proportion of winners who had lost the last election for the top and bottom thirds of the cohesion range. Parties in the bottom third of the cohesion range nominated last-election losers twice as often as parties in the top third.

Figure 5 does not speak to candidates recruited from other parties, nor who did not run in the previous election. To get a better sense of candidates' independent popularity, we can look at the backgrounds of the candidates themselves. The rightmost column of Table 4 describes whatever council member was new to the party for the respective term. Before looking at those descriptions, note three historic accounts of endorsement politics in Cincinnati and Worcester. Burnham (1997) argues that the post-reform Cincinnati GOP initially refused to nominate black candidates. This refusal provoked an independent candidacy in 1927. Beginning in 1929 and continuing through 1951, the GOP thereafter endorsed one black candidate in each election. In 1943, Charter's component parties felt similar pressure to begin slating women (Burnham 2013: 58). ${ }^{22}$ Finally, our best description of Worcester city politics notes competition among Irish-Americans, Italian-Americans, and Jews (Binstock 1960: 2.34-35, 3.5-6, 6.15).

Space constraints prevent extended discussion of the lone wolves, but Rice scores recover the historical literature's insights. The Cincinnati GOP begins endorsing black candidates during its post-reform nadir. Then it turns to labor figures in the mid-New Deal, when elections are returning hung councils in the presence of a third-party challenge (Kolesar 1995). Charter Republicans turn to women in the middle of World War II. The Democrats then bid for support of black Republicans. Around the same time, Republicans nominate a prominent county prosecutor. In Worcester, the contending Democratic factions - the regular party, plus the CEA Democrats who broke with it - compete for the allegiance of Jews and Italian-Americans as dictated by their seat-maximization needs.

to the Democratic Party. See, e.g., Brady Black, "Significant Points Abound in City Election; If Republicans Elect Five, Who'll They Be?," Cincinnati Enquirer, November 3, 1953.

22. Other descriptions of Cincinnati lone wolves are drawn from Straetz (1958). 


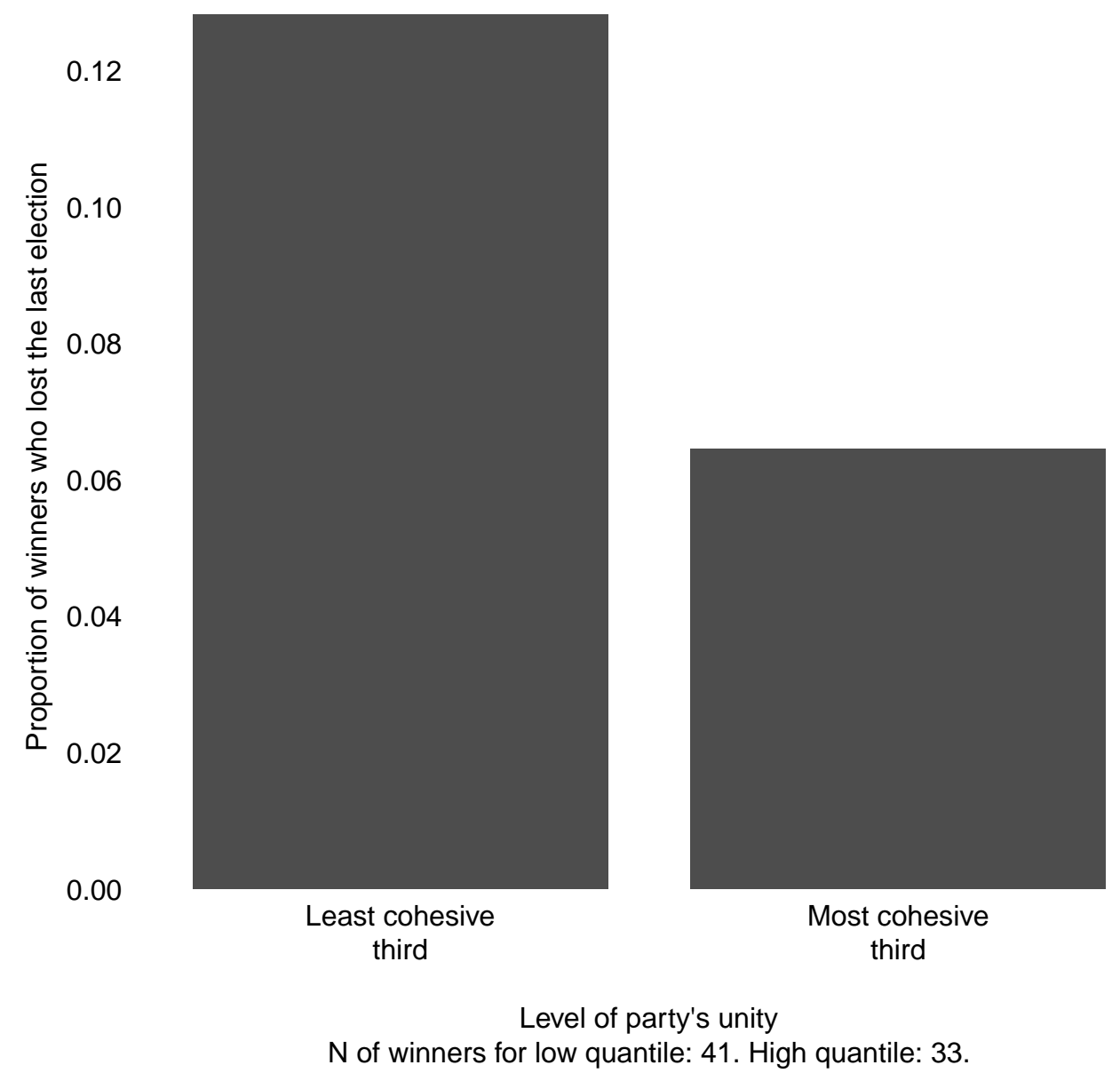

Figure 5: Endorsement of last-election losers by parties in the bottom and top thirds of the Rice cohesion distribution. 


\section{Implications}

I have shown that legislative cohesion under historic STV elections could be high, low, or in between. It was high when parties campaigned as teams and low when candidates put themselves ahead of party. Parties nonetheless endorsed such candidates when minority status (in council or a pre-election coalition) made that strategy worthwhile. In sum, historic STV elections suggest a strategic context in which majority-seeking parties reach beyond their traditional bases of support. There was a tradeoff between winning elections and cohesion in government.

The winning-cohesion tradeoff ought to exist today if we were to apply STV once again. We would not see a second layer of competition for control of the mayoralty, unless that city (or state) operated under a template council-manager system. We would measure party-oriented electoral coordination differently as a result. Overall, though, parties still aim for legislative majorities. That would be true under the Beyer bill as well. Parties in Congressional elections target marginal seats. Under RCV, we might expect them to target competitive multi-seat districts or even the most marginal seat in any given district. And the winning-cohesion tradeoff would hold to the extent that winning the marginal seat required tapping new constituencies, co-opting opposing-party "centrists," or reaching out to unaffiliated candidates whose bases of support were growing.

One way to raise legislative cohesion in that context would be to do what Ireland does: deny ballot access to people without permission from party officers. That raises questions of its own. If a "lone wolf" candidate is popular enough to induce major-party endorsement, what is to stop them from forming their own party? In the late 1930s, Cincinnati hosted a popular left-wing party that did not join (or was not invited to join) the Charter pre-election coalition. These Progressive Democrats held the council balance until the GOP absorbed them in 1941 (Straetz 1958: 129-34). Black candidates reflect a similar story: shunned in 1927 and 1929, then incorporated in 1931. In Worcester, competition for votes eventually brought Jews into the regular Democratic Party.

It appears that ranked-choice voting makes parties work a little harder. Whether that is good or bad depends on the value we give party discipline. 


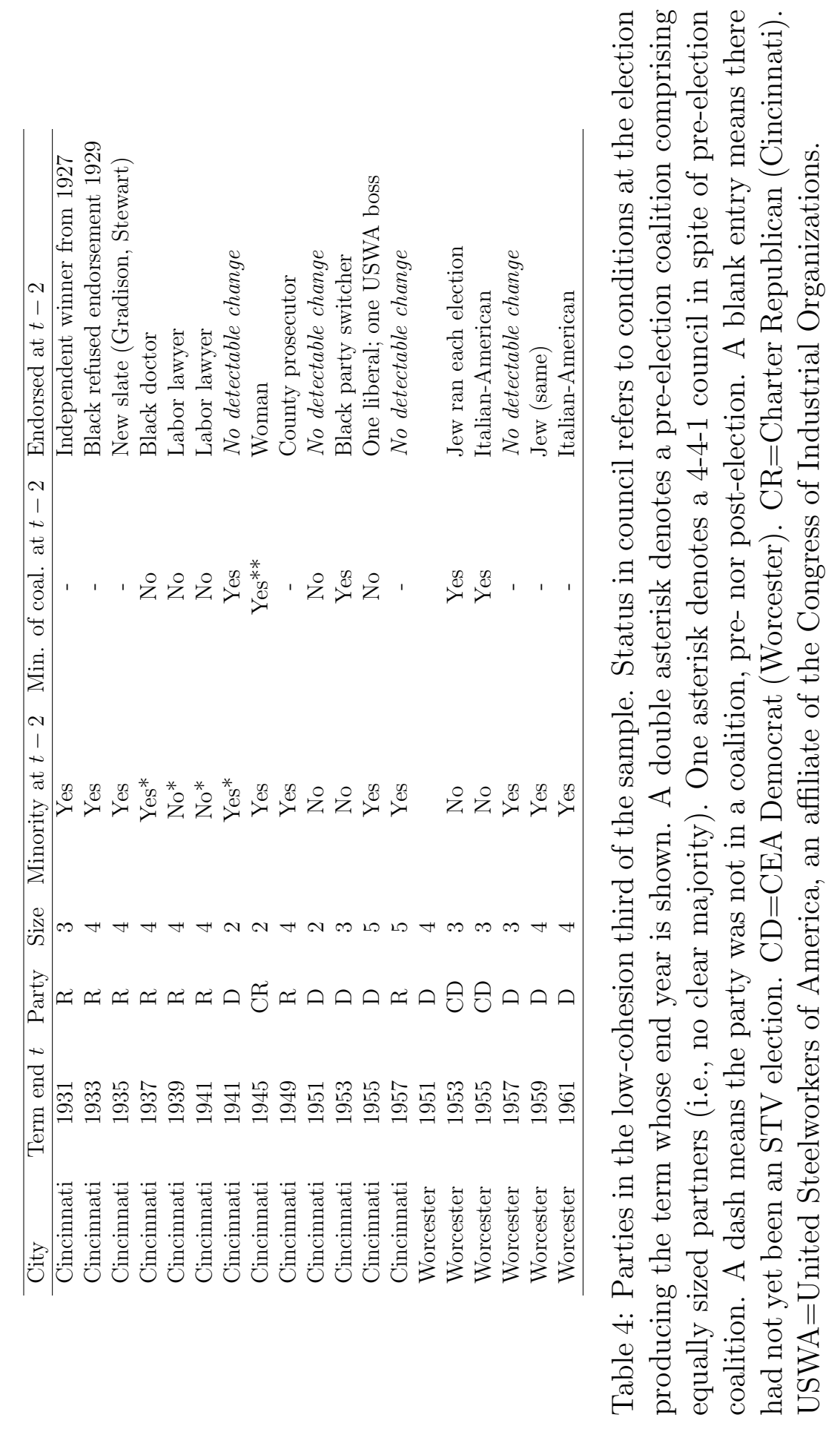




\section{References}

Aldrich, John. 1995. Why Parties? The Origin and Transformation of Party Politics in America. Chicago, IL: University of Chicago Press.

Alvarez, R. Michael, and Betsy Sinclair. 2012. "Electoral Institutions and Legislative Behavior: The Effects of Primary Processes." Political Research Quarterly 65 (3): 544-557. doi:10.1177/1065912911411098.

Ames, Barry. 2001. "Party Discipline in the Chamber of Deputies." Chap. 7 in The Deadlock of Democracy in Brazil, 187-223. Ann Arbor: University of Michigan Press.

Amy, Douglas J. 1993. Real Choices / New Voices: How Proportional Representation Elections Could Revitalize American Democracy. New York: Columbia University Press.

- 1996. "The Forgotten History of the Single Transferable Vote in the United States." Representation 34 (1): 13-20.

- 2002. Real Choices / New Voices: How Proportional Representation Elections Could Revitalize American Democracy. 2nd ed. New York: Columbia University Press.

Austin, Rory Allan. 2002. "Seats That May Not Matter: Testing for Racial Polarization in U.S. City Councils." Legislative Studies Quarterly 27 (3): 481-508. doi:10.2307/3598574.

Bagashka, Tanya, and Jennifer Hayes Clark. 2014. "Electoral Incentives and Legislative Organization: An Examination of Committee Autonomy in U.S. State Legislatures." State Politics 8 Policy Quarterly 14 (3): 297320. doi:10.1177/1532440014536408.

Banfield, Edward C., and James Q. Wilson. 1966. City Politics. Cambridge, MA: Harvard University Press.

Bawn, Kathleen, Marty Cohen, David Karol, Seth Masket, Hans Noel, and John Zaller. 2012. "A Theory of Political Parties: Groups, Policy Demands, and Nominations in American Politics." Perspectives on Politics 10, no. 3 (September): 571-597. 
Bergman, Matthew E., and Matthew S. Shugart. 2013. "Patterns of Intraparty Competition in Open-list and SNTV Systems." Electoral Studies 32:321-333. doi:10.1016/j.electstud.2013.01.004.

Binstock, Robert H. 1960. A Report on Politics in Worcester, Massachusetts. Technical report. Cambridge, MA: Joint Center for Urban Studies of the Massachusetts Institute of Technology and Harvard University.

Bloomfield, Charles Alpheus. 1926. "Ashtabula's Experience with Proportional Representation." Master's thesis, Columbia University.

Bucchianeri, Peter. 2017. "Political Parties, Local Cleavages, and the Dimensionality of Legislative Conflict: Evidence from City and County Councils." Paper presented at the 2017 Annual Meeting of the Midwest Political Science Association, Chicago, IL.

Burnett, Craig M. 2017. "Parties as an Organizational Force on Nonpartisan City Councils." Early online version. Party Politics. doi:10.1177/ 1354068817737996.

Burnett, Craig M., and Vladimir Kogan. 2015. "Ballot (and Voter) "Exhaustion" under Instant Runoff Voting: An Examination of four Rankedchoice Elections." Electoral Studies 37:41-49. doi:10.1016/j . electstud. 2014.11.006.

Burnham, Robert A. 1997. "Reform, Politics, and Race in Cincinnati: Proportional Representation and the City Charter Committee, 1924-1959." Journal of Urban History 23, no. 2 (January): 131-163.

—. 2013. "Women and Reform in Cincinnati: Responsible Citizenship and the Politics of 'Good Government,' 1924-1955." Ohio Valley History $13(2): 48-69$.

Busch, Ronald J. 1995. "Ashtabula: The Pioneer Community." Chap. 4 in Proportional Representation and Election Reform in Ohio, edited by Kathleen L. Barber, 83-115. Ohio State University Press.

Cain, Bruce, John Ferejohn, and Morris Fiorina. 1987. The Personal Vote: Constituency Service and Electoral Independence. Cambridge, MA: Harvard University Press. 
Calabrese, Stephen. 2006. "An Explanation of the Continuting Federal Government Mandate of Single-member Congressional Districts." Public Choice 130 (January): 23-40.

Carey, John M. 2007. "Competing Principals, Political Institutions, and Party Unity in Legislative Voting." American Journal of Political Science 51 (1): $92-107$.

Carey, John M., and Matthew S. Shugart. 1995. "Incentives to Cultivate a Personal Vote: A Rank Ordering of Electoral Formulas." Electoral Studies 14 (4): 417-439.

Citizens' Information Board. 2017a. "Nomination of candidates for membership of Dáil Éireann." Republic of Ireland. http: //www . citizensinformation . ie/en/government_in_ireland/elections_and_referenda/national_ elections/nomination_for_membership_of_dail_eireann.html.

. 2017b. "Registering a political party in Ireland." Republic of Ireland. http : / / www . citizensinformation . ie/en/government_in_ ireland / national_\%20government/houses_of _ the_oireachtas / registering_a_political_party.html.

Clark, Alistair. 2012. "Party Organization and concurrent multi-level local campaigning: The 2007 Scottish elections under MMP and STV." Party Politics 18, no. 4 (July): 603-622.

Cohen, Marty, David Karol, Hans Noel, and John Zaller. 2008. The Party Decides: Presidential Nominations Before and After Reform. Chicago, IL: University of Chicago Press.

Cox, Gary W. 1997. Making Votes Count: Strategic Coordination in the World's Electoral Systems. Cambridge University Press.

Crespin, Michael H., David W. Rohde, and Ryan J. Vander Wielen. 2011. "Measuring Variations in Party Unity Voting: An Assessment of Agenda Effects." Party Politics 19 (3): 432-57. doi:10.1177/1354068811407578.

Depauw, Sam, and Shane Martin. 2009. "Legislative Party Discipline and Cohesion in Comparative Perspective." In Intra-Party Politics and Coalition Government, edited by D. Giannetti and Michael Laver, 103-120. Abingdon: Routledge. 
Desposato, Scott W. 2005. "Correcting for Small Group Inflation of Roll-Call Cohesion Scores." British Journal of Political Science 35:731-44.

. 2006. "The Impact of Electoral Rules on Legislative Parties: Lessons from the Brazilian Senate and Chamber of Deputies." Journal of Politics 68 (4): 1015-27.

Donovan, Todd. 2014. "Candidate Perceptions of Campaigns under Preferential and Plurality Voting." Unpublished manuscript.

Donovan, Todd, Caroline Tolbert, and Kellen Gracey. 2016. "Campaign Civility under Preferential and Plurality Voting." Electoral Studies 42:157163. doi:10.1016/j.electstud.2016.02.009.

Drutman, Lee. 2016. Political Dynamism: A New Approach to Making Government Work Again. White paper. New America Foundation.

Farrell, David M., and Richard S. Katz. 2014. "Assessing the Proportionality of the Single Transferable Vote." Representation 50 (1): 13-26.

Frederickson, H. George, Gary A. Johnson, and Curtis H. Wood. 2004. The Adapted City: Institutional Dynamics and Structural Change. London, UK: M.E. Sharpe.

Gray, Kenneth E. 1959. A Report on Politics in Cincinnati. Technical report. Cambridge, MA: Joint Center for Urban Studies of the Massachusetts Institute of Technology and Harvard University.

Hallett, George Hervey. 1937. Proportional Representation: The Key to Democracy. Washington, DC: National Home Library Foundation.

Haspel, Moshe, Thomas F. Remington, and Steven S. Smith. 1998. "Electoral Institutions and Party Cohesion in the Russian Duma." Journal of Politics 60 (2): 417-439.

Hassell, Hans J. G. 2015. "Party Control of Party Primaries: Party Influence in Nominations for the US Senate." Journal of Politics 78 (1). doi:10. $1086 / 683072$.

Hatton, Augustus R. 1916. "The Ashtabula Plan: The Latest Step in Municipal Organization." National Municipal Review 5, no. 1 (January): $56-65$. 
Heisel, W. Donald. 1982. "Abandonment of Proportional Representaton and the Impact of 9-X voting in Cincinnati." Presented at the Annual Meeting of the American Political Science Association.

Hermens, Ferdinand A. 1940. Democracy and Proportional Representation. Chicago: University of Chicago Press.

. 1941. Democracy or Anarchy? A Study of Proportional Representation. Vol. 1. Notre Dame, IN: University of Notre Dame.

1943. P.R., Democracy, and Good Government. South Bend, IN: The Review of Politics, University of Notre Dame.

_. 1984. "Representation and Proportional Representation." Chap. 2 in Choosing an Electoral System: Issues and Alternatives, edited by Arend Lijphart and Bernard Grofman, 15-30. New York, NY: Praeger.

Hirczy de Miño, Wolfgang, and John C. Lane. 1996. "STV in Malta: Some Surprises." Representation 34 (1): 21-28. doi:10.1080/00344899608522982.

- 2000. "Malta: STV in a Two-Party System." Chap. 9 in Elections in Australia, Ireland, and Malta under the Single Transferable Vote: Reflections on an Embedded Institution, edited by Shaun Bowler and Bernard Grofman, 178-204. Ann Arbor, MI: University of Michigan Press.

Hirschman, Albert O. 1964. "The Paternity of an Index." American Economic Review 54 (5): 761.

Hoag, Clarence Gilbert. 1914. "The P.R. Review: An Announcement." Proportional Representation Review 3, no. 32 (October): 2.

- 1923. "Proportional Representation in the United States: Its Spread, Principles of Operation, Relation to Direct Primaries, and General Results." Annals of the American Academy of Political and Social Science 106 (March): 105-110.

Hoag, Clarence Gilbert, and George Hervey Hallett. 1926. Proportional Representation. New York: Macmillan.

1932. "Consolidation of the P.R. League and the National Municipal League." Proportional Representation Review 3, no. 102 (April): 1. 
Jun, Hae-Won, and Simon Hix. 2010. "Electoral Systems, Political Career Paths and Legislative Behavior: Evidence from South Korea's MixedMember System." Japanese Journal of Political Science 11 (2): 153171. doi:10.1017/S1468109910000058.

Karol, David. 2009. Party Position Change in American Politics: Coalition Management. Cambridge: Cambridge University Press.

Kimball, David C., and Joseph Anthony. 2016. "Voter Participation with Ranked Choice Voting in the United States." Unpublished manuscript. October. http://www . umsl. edu/ kimballd/KimballRCV.pdf.

_ 2018. "Ranked Choice Voting: A Different Way of Casting and Counting Votes." Chap. 8 in Chanigng How America Votes, edited by Todd Donovan, 100-112. New York: Rowman \& Littlefield.

Kolesar, Robert J. 1995. "PR in Cincinnati: From 'Good Government' to the Politics of Inclusion?" Chap. 6 in Proportional Representation and Election Reform in Ohio, edited by Kathleen L. Barber, 160-208. Ohio State University Press.

Kunicova, Jana, and Thomas F. Remington. 2008. "Mandates, Parties, and Dissent: Effect of Electoral Rules on Parliamentary Party Cohesion in the Russian State Duma, 1994-2003." Party Politics 14 (5): 555-574. doi:10.1177/1354068808093390.

Lijphart, Arend. 2015. "Polarization and Democratization." Chap. 4 in Solutions to Political Polarization in America, edited by Nathaniel Persily, 73-82. New York: Cambridge University Press.

Limongi, Fernando, and Argelina Maria Cheibub Figueiredo. 1995. "Partidos Políticos na Câmara dos Deputados: 1989-1994." Dados 38 (3): 497-527.

Mayhew, David R. 1974. Congress: The Electoral Connection. New Haven, CT: Yale University Press.

McDaniel, Jason A. 2016. "Writing the Rules to Rank the Candidates: Examining the Impact of Instant-Runoff Voting on Racial Group Turnout in San Francisco Mayoral Elections." Journal of Urban Affairs 38 (3): 387-408. doi:10.1111/juaf. 12209. 
Miller, Gary, and Norman Schofield. 2003. "Activists and Partian Realignment in the United States." American Political Science Review 97 (2): 245-60.

Moley, Raymond. 1918. "Representation in Dayton and Ashtabula." National Municipal Review 7, no. 1 (January): 27-35.

Neely, Francis, and Corey Cook. 2008. "Whose Votes Count? Undervotes, Overvotes, and Ranking in San Francisco's Instant-Runoff Elections." American Politics Research 36 (4): 530-554.

Neely, Francis, Corey Cook, and Lisel Blash. 2005. An Assessment of Rankedchoice Voting in the San Franscisco 2004 Election. Technical report. Public Research Institute, San Francisco State University.

Neely, Francis, and Jason A. McDaniel. 2015. "Overvoting and the Equality of Voice under Instant-Runoff Voting in San Francisco." California Journal of Politics 8 Policy 7 (4): 1-27. doi:10.5070/P2cjpp7428929.

Noel, Hans. 2016. "Separating Ideology from Party in Roll Call Data." Paper presented at the 2016 Annual Meeting of the American Political Science Association, Philadelphia, PA.

Olivella, Santiago, and Margit Tavits. 2013. "Legislative Effects of Electoral Mandates." British Journal of Political Science 44:301-321. doi:10 . 1017/S0007123412000828.

Owens, John E. 2003. "Explaining Party Cohesion and Discipline in Democratic Legislatures: Purposiveness and Contexts." Journal of Legislative Studies 9 (4): 12-40. doi:10.1080/1357233042000306236.

Pearson, Kathryn. 2015. "Party Loyalty and the Potential Mechanisms of Party Discipline." Chap. 3 in Party Discipline in the U.S. House of Representatives, 53-74. Ann Arbor: University of Michigan Press.

Poole, Keith T. 2000. "Nonparametric Unfolding of Binary Choice Data." Political Analysis 8 (3): 211-237.

— 2005. Spatial Models of Parliamentary Voting. New York: Cambridge University Press.

Poole, Keith T., and Howard Rosenthal. 1997. Congress: A Political-Economic History of Roll Call Voting. New York, NY: Oxford University Press. 
Reed, Thomas H., Doris D. Reed, and Ralph A. Straetz. 1957. Has PR Worked for the Good of Cincinnati? An Appraisal of Cincinnati's Method of Electing Council, 1925-1956. Cincinnati, OH: Stephen H. Wilder Foundation.

Rice, Stuart A. 1925. "The Behavior of Legislative Groups: A Method of Measurement." Political Science Quarterly 40 (1): 60-72.

Rosenthal, Howard, and Erik Voeten. 2004. "Analyzing Roll Calls with Perfect Spatial Voting: France 1946-1958." American Journal of Political Science 48, no. 3 (July): 620-632.

Salam, Reihan, and Rob Richie. 2017. "How to Make Congress Bipartisan." The New York Times (July 7): A19. https://www.nytimes.com/2017/ 07/07/opinion/how-to-make-congress-bipartisan.html.

Schultz, David, and Kristi Rendahl. 2010. Evaluating Ranked Choice Voting in the 2009 Minneapolis Elections: A Report for the Minneapolis Elections Division. Technical report. Minneapolis Elections Division.

Schwartz, Thomas. 1989. "Why Parties?" Unpublished manuscript. July.

Shomer, Yael. 2016. "The Conditional Effect of Electoral Systems and Intraparty Candidate Selection Processes on Parties' Behavior." Online preprint. Legislative Studies Quarterly. doi:10.1111/1sq.12141.

- 2017. "Institutional reforms and their effect on legislators' behavior: The Israeli experience, 1992-2011." Party Politics 23 (3): 297-308. doi:10.1177/1354068815595213.

Sinnott, Richard. 1999. "The Electoral System." Chap. 4 in Politics in the Republic of Ireland, edited by John Coakley and Michael Gallagher, 99126. New York \& London: Routledge.

Stegmaier, Mary, Kamil Marcinkiewicz, and Michael Jankowski. 2016. "The Effects of Electoral Rules on Parliamentary Behavior: A Comparative Analysis of Poland and the Czech Republic." East European Politics and Societies and Cultures 30 (4): 885-906. doi:10.1177/0888325416670240.

Straetz, Ralph A. 1958. PR Politics in Cincinnati: Thirty-two Years of City Government through Proportional Representation. New York, NY: New York University Press. 
Taft, Charles Phelps. 1971. City Management: The Cincinnati Experience. Port Washington, NY: Kennikat Press.

Tanzer, Laurence Arnold. 1937. The New York City Charter. New York: Clark Boardman Co.

Tavits, Margit. 2009. "The Making of Mavericks: Local Loyalties and Party Defection." Comparative Political Studies 42 (6): 793-815. doi:10.1177/ 0010414008329900.

Thompson, Carl. 1913. "The Vital Points in Charter Making from a Socialist Point of View." National Municipal Review 2, no. 3 (July): 416-426.

Tolbert, Caroline J. 2014. "Experiments in Election Reform: Voter Perceptions of Campaigns Under Preferential and Plurality Voting." Unpublished manuscript.

Weaver, Leon. 1986. "The Rise, Decline, and Resurrection of Proportional Representation in Local Governments in the United States." Chap. 8 in Electoral Laws and their Political Consequences, edited by Bernard Grofman and Arend Lijphart, 139-153. New York, NY: Agathon Press. 